\title{
A bio-economic analysis of long term changes in the production of French fishing fleets operating in the Bay of Biscay
}

\author{
Fabien Steinmetz ${ }^{1, a}$, Olivier Thébaud ${ }^{2}$, Fabian Blanchard ${ }^{3}$, Pascal Le Floch ${ }^{2}$ and Julien Bihel ${ }^{2}$ \\ ${ }^{1}$ UMR AMURE, Université de Bretagne Occidentale, 12 rue Kergoat, CS 93837, 29238 Brest, France \\ 2 IFREMER, Marine Economic Dept, UMR-AMURE, BP 70, 29280 Plouzané, France \\ 3 IFREMER, Dep. Halieutique Méditerranéen \& Tropical, Cayenne 97331, French Guiana
}

Recieved 18 September 2007; Accepted 12 May 2008

\begin{abstract}
Selective fishing pressure on more highly valued marine living resources is one of the key factors proposed to explain changes occurring in fish communities and associated landings of commercial fisheries. The aim of this paper is to establish the nature of changes in the landings of French fishing fleets operating in the Bay of Biscay in the period 1973-2002, and whether these changes could be related to the relative economic attractiveness of different fish species. The analysis focuses on trends observed in the landings of all commercial fish species over the last three decades. It is based on data of annual quantities landed and ex-vessel prices compiled from official French landings records, and on bio-geographical descriptors of these species derived from published data. Using simple index numbers and multivariate analysis, we examined changes in total landings in terms of their volume and value, as well as changes in their composition. We show that the composition of landings significantly changed over the study period, with an increase in the proportion of pelagic species, of lower economic value. The average ex-vessel price of production by the fleets tended to decrease from the late 1980s; partly due to a cross-species drop in prices, occurring mainly after 1993, but also to the increased proportion of low-priced species in the landings. This caused a significant drop in the total gross value of production in the second half of the study period.
\end{abstract}

Key words: French fisheries production / Bio-economic analysis / Long-term changes / Bay of Biscay / North-Eastern Atlantic

\begin{abstract}
Résumé - Analyse bio-économique des changements de long terme de la production des flottilles de pêche françaises opérant dans le golfe de Gascogne. La pression de pêche sélective sur les ressources marines vivantes de forte valeur est un des facteurs-clés proposés pour expliquer les changements qui surviennent dans la structure des communautés de poisson et dans les débarquements des pêcheries commerciales associés. L'objectif de cet article est d'établir la nature des changements dans les débarquements des flottilles de pêche françaises opérant dans le golfe de Gascogne, et d'examiner les relations entre ces changements et l'attractivité relative des espèces de poisson d'un point de vue économique. L'analyse se concentre sur les tendances observées au cours des trois dernières décennies dans les débarquements de toutes les espèces commerciales de poissons effectués par les flottilles de pêche opérant dans le golfe. Elle s'appuie sur des données concernant les quantités annuelles débarquées, les prix compilés à partir des enregistrements officiels des débarquements français, et les données publiées concernant les caractéristiques biogéographiques des espèces étudiées. En s'appuyant sur des indices simples et une analyse multivariée, on examine les changements des débarquements totaux en volume et en valeur, ainsi que les changements dans leur composition. On montre que la composition des débarquements a fortement changé au cours de la période étudiée, avec un accroissement important de la part des espèces pélagiques, de plus faible valeur. Le prix moyen de la production a eu tendance à décroître depuis la fin des années 1980. Ceci est en partie dû à une chute des prix de l'ensemble des espèces, après 1993, et en partie lié à l'accroissement de la part des espèces de plus faible valeur dans les débarquements. Une baisse importante de la valeur de la production en a découlé sur cette deuxième moitié de la période d'étude.
\end{abstract}

\section{Introduction}

In many fisheries around the world, major changes have been observed in the composition of fish landings, such as a

\footnotetext{
a Corresponding author: fabien.steinmetz@ifremer.fr
}

reduction in average individual size and the mean trophic level of fish caught (Pauly 1998). These changes have been considered to be a possible consequence of modifications in biological communities due to the effects of fishing on the ecosystem (National Research Council 2006). Such modifications were 
observed in the groundfish communities of the Bay of Biscay, following trawling surveys carried out by Ifremer with oceanographic research vessels. In addition to modifications in the size and trophic level of fish, potentially due to the effects of fishing, the survey data showed that subtropical fish species seemed to be favoured compared with more boreal ones. The combined effects of fishing and global warming were advocated to explain these observations (Poulard and Blanchard 2005; Blanchard and Vandermeirsch 2005; Blanchard et al. 2006).

Most studies to date have focused mainly on the ecological dimensions of composition changes in fish communities and the landings of associated fisheries, while the economic dimensions of these modifications have not been explored, particularly from an empirical standpoint. Few studies have focused on the economic drivers behind the sequential harvesting of different fish species in a community, and the economic consequences of changes in the landing composition. Thébaud and Soulié (2008) proposed a simple bio-economic model to examine these issues, although their approach remained theoretical. Sumailla (1998) discussed the implications of taking into account economic characteristics of the production extracted from marine communities, underlining the role of market responses in the determination of overall economic impacts of changes in landing composition. Pinnegar et al. (2002) analyzed this in the context of the Celtic Sea fisheries, showing that there had been a long-term decrease in the average trophic level of fish landings from this area. This trophic change was accompanied by changes in the relative price of species landed reflecting a modification in the relative availability of species at different trophic levels. Species of low trophic level became increasingly abundant in landings, relative to species of high trophic levels, leading to the relative price of the former decreasing, for a given demand for these species. Steinmetz et al. (2006) analyzed the long-term trends in the landings of all species caught by French commercial fishing fleets in the North-East (NE) Atlantic, looking at the ecological descriptors of landings, their economic value and the relationships between the composition of landings and their economic value. These authors concluded that a more in-depth analysis was required to assess the nature and extent of interactions between changes in landings and economic variables such as the relative prices of landed species.

We analyze these interactions on long-term changes in the composition of landings by French fleets operating in the NE Atlantic. The analysis focuses on a selection of fish species, and covers the period 1973-2002. While our analysis centred on the fisheries of the Bay of Biscay. A comparison of trends was also made with those previously observed at the larger scale of the NE Atlantic. We analyze the relationships between the ecological status of species composing the production of fishing fleets, the relative prices of these species, and the economic value of landings, at these two scales.

\section{Materials and methods}

The analysis was based on existing data on the evolution of landings of a selection of marine species by French fleets operating in the NE Atlantic, and more specifically in the Bay
Table 1. Origin of the data used in the analysis.

\begin{tabular}{c|c|c}
\hline & NE Atlantic & $\begin{array}{l}\text { Bay of Biscay } \\
\text { (ICES }^{3} \text { VIIIa,b) }\end{array}$ \\
\hline $\begin{array}{c}\text { 1 Landings by } \\
\text { species (tons) }\end{array}$ & $\begin{array}{l}\text { Cahiers CCPM } \\
\text { DPMA }^{4} \text {, OFIMER } \\
\text { data }\end{array}$ & $\begin{array}{l}\text { ICES }^{3} \text { VIII a,b } \\
\text { landings data }\end{array}$ \\
\hline $\begin{array}{c}\text { 2 Price per species } \\
\text { (euros, 2002) }\end{array}$ & \multicolumn{2}{|c}{ Cahiers CCPM ${ }^{1}$, OFIMER $^{2}$, DPMA $^{4}$} \\
\hline $\begin{array}{c}\text { 3 Ecological } \\
\text { descriptors of } \\
\text { fish species }\end{array}$ & \multicolumn{1}{|c}{ FishBase, } \\
\hline
\end{tabular}

${ }^{1}$ French Central Committee of Maritime Fishing; ${ }^{2}$ French National Interprofessional Office of Sea Products and Aquaculture; ${ }^{3}$ International Council for the Exploration of the Sea; ${ }^{4}$ French Maritime Fishing and Aquaculture Directorate; ${ }^{5}$ Food and Agriculture Organization.

of Biscay (ICES areas VIIIa,b), over the period 1973-2002. Species selected for the analysis were restricted to marine fishes cited in landings records for French fleets operating in these two areas (see Appendix for the list of species) ${ }^{1}$.

Table 1 lists the sources of the different data sets used in the analysis. Data used concerned: (i) annual production in volume and mean ex-vessel price per species, originating from the NE Atlantic and the Bay of Biscay and landed by French fleets and (ii) descriptors of the bio-geographic characteristics of each species.

Two sources of data were used for fisheries production. Firstly, annual reports of French landings established by the French Marine Fisheries and Aquaculture Directorate in collaboration with the agency for fisheries products (Office des Produits de la Mer) and the Central Committee for Maritime Fisheries, were used to construct a dataset of French production originating from the NE Atlantic over the study period. This information concerned both the volume of annual landings and average annual first sale prices of fresh fish per species. Because records were only available at the national level, other sources of information were used to exclude landings originating from other areas, particularly the Mediterranean. Such data sources included the FAO catches and landings data per area $^{2}$, and expert knowledge from French fisheries specialists. Current prices for landings from the NE Atlantic were converted to constant prices, using the French consumption price index, with 2002 as the base year.

Secondly, official data on landings by French fleets of the same species originating from the Bay of Biscay (ICES area VIII $a, b)$ were extracted from the ICES database ${ }^{3}$. Information available in this database concerns annual tonnage landed per species for the production of French fisheries in the NE Atlantic, with the exclusion of year 1999 for which no official data was available. In the absence of alternative sources of information covering the same time period, average prices recorded for landings of fresh fish caught in the NE Atlantic

\footnotetext{
1 Analysis of trends observed in the landings of a larger selection of species, including shellfish and molluscs, by the same fleets, is presented in Steinmetz et al. (2006).

2 http://www.fao.org/fi

${ }^{3}$ http://www.ices.dk/fish/statlant.asp
} 
were used to calculate the value of landings originating from the Bay of Biscay. The assumption here, which we were not able to verify, is that both the relative ex-vessel prices of fish species and the trends registered in these prices were similar at the two scales ${ }^{4}$.

While the data sets included all major commercial species listed in the annual reports, the data used for the present analysis concerned only 57 fish species for which information was available. Taken together over the 1973 to 2002 period, landings of these species constituted $50 \%$ of the total volume of French landings originating from the Bay of Biscay, and 78\% of the total volume of French landings originating from the NE Atlantic. French landings of these species originating from the Bay of Biscay represented on average $24 \%$ in volume of the total annual landings from the bay, a proportion which remained relatively stable throughout the period, following a slight increase in the late $1970 \mathrm{~s}$.

In order to characterize the production of French fleets from an ecological perspective, analysis of bio-geographic characteristics of fish species was included (Table 1); these were extracted from FishBase and from Quéro and Vayne (1997).

\section{Analysis methods}

The analysis was carried out in three steps. First, trends observed in the total volume and value landed by the French fleets were analysed based on Fisher indices of changes in the volume, prices and value of production. Indices were calculated and compared at the two scales of analysis: NE Atlantic and Bay of Biscay.

Fisher indices were calculated as the geometric mean of Paasche and Laspeyres indices. The Paasche index uses the most recent year as a base while the Laspeyres index uses the first year of the series as a base in weighting the contribution of each species to the average value of the variable under consideration. For example, a Fisher index of the volume of landings is calculated as follows:

$$
F_{t / 0}^{q}=\sqrt{\frac{\sum_{i}\left(p_{i, 0} \cdot q_{i, t}\right)}{\sum_{i}\left(p_{i, 0} \cdot q_{i, 0}\right)} \times \frac{\sum_{i}\left(p_{i, t} \cdot q_{i, t}\right)}{\sum_{i}\left(p_{i, t} \cdot q_{i, 0}\right)}}
$$

where $p_{i, t}$ is the price of species $i$ at time $t, q_{i, t}$ the volume landed of species $i$ at time $t$. A similar equation was used to calculate the Fisher index of prices. Using the Fisher index minimizes potential biases arising from the influence of the base chosen to weight the contributions of each species according to changes in the average price or volume of landings. Given that the analysis considered a fairly long time period, during which significant changes could be observed in the structure of production in terms of volume and/or relative prices, our use of this index allowed us to characterize the overall changes in

\footnotetext{
${ }^{4}$ In principle, there could be differences in prices between the two scales, with higher prices observed for landings of fish caught in the Bay of Biscay, a greater proportion of which are marketed fresh after shorter fishing trips and are hence of better quality than fish caught offshore and landed frozen. As our analysis was restricted to fresh fish landings, these differences are probably limited.
}

prices and volumes landed while minimizing bias due to structural changes. We also used the property of equivalence between the product of the Fisher price and volume indices and the simple value index (Diewert 1996), to assess the relative contribution of changes in prices and volumes to the overall change in value over the time period.

The second step of the analysis was to explore the associated changes in the composition of landings underlying the modifications observed in total production. This was done by first analyzing trends in landings of species by group, distinguishing benthic, demersal and pelagic species. To test for significant long-term trends, non-parametric Mann-Kendall tests were performed (Gilbert 1987). The Mann-Kendall test is particularly useful because data need not conform to any particular distribution. Where a significant linear trend was indicated, the true slope (change per year) was estimated using the procedure developed by Sen (1968). Secondly, simple indices of the biogeographic characteristics of landings were calculated at the two scales of analysis using the following indicators: (1) maximal length of individual fish of each species, (2) trophic level of each species at the adult phase and (3) median latitude of the area over which the species is known to be distributed.

Weighted averages of these variables were calculated based on the proportion of each species in total landings of the 57 fish species considered.

The third step was to carry out a multivariate analysis of the evolution of landings. Correlations between changes in the composition of landings and the ecological characteristics of landed species were first investigated using principal component analysis (PCA). In order to capture the dynamics of exploitation, years of landings (30 for the NE Atlantic, 32 for the Bay of Biscay) were used as active variables in the analysis, with individual observations corresponding to each of the 57 species. The analysis was centred and normalized. As our objective was to study the evolution of the structure of landings, i.e. the relative contribution of each species to total landings, years of landing (variables) were uniformly weighted in the analysis, whereas species (observations) were weighted according to their respective proportions in the total volume landed over the period. Then, we used bio-geographic descriptors of the species as illustrative variables in the analysis, to establish the nature of correlations between these descriptors and the years of landings. The descriptors included for each species were: the Von Bertalanffy growth coefficient; maximum weight, length and age; trophic level; and median latitude and longitude of the area over which the species is known to be distributed.

In addition, our analysis sought to establish whether correlations existed between the position of individual species in the past record of changes in production patterns, and the economic status of these species. This was done by defining a set of three price classes for individual species for which ex-vessel prices were available (35 out of 57 species): 1) species with high average prices over the period, 2) species with medium average prices over the period, and 3) species with low average prices over the period ${ }^{5}$ (see this classification in Table 2 and Fig. 1). The price classes were then used to characterize

\footnotetext{
5 According to our classification of species, the intermediate price group is slightly smaller than the other two groups in terms of total
} 
Table 2. Price data class (euros 2002).

\begin{tabular}{ll}
\hline $0:$ No price data & 21 species \\
\hline $1:$ Low price class $[0-1.75]$ & 14 species \\
$2:$ Medium price class [1.75-4] & 11 species \\
$3:$ High price class [4-12.5] & 10 species \\
\hline
\end{tabular}

Mean price by species through the period, using 2002 constant price data.

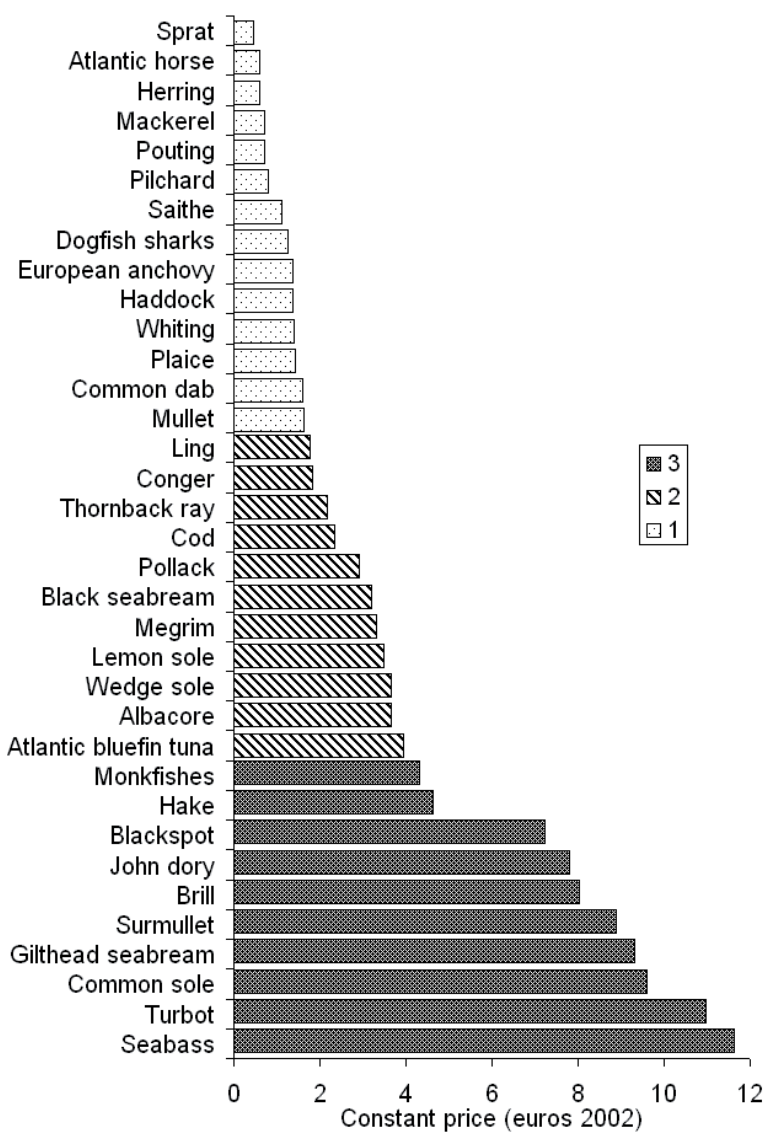

Fig. 1. Mean constant price per species, sorted by price class. Source: IFREMER, based on ICES and CCPM-OFIMER-DPMA data (see Table 1).

individual species in the first space of the PCA, and this was used to assess whether relations existed between the evolution in the structure of landings and the relative prices of the species.

\section{Results}

Results of the analysis are presented in the following order: first, the overall trends observed in the total volume and value of landings by French fleets at the two scales of analysis are described using the indices defined above; second, changes in the species composition of these landings are analyzed, and the nature of these changes considered, based on ecological

weight of landings, while the high and low price groups have a similar weight throughout the period.
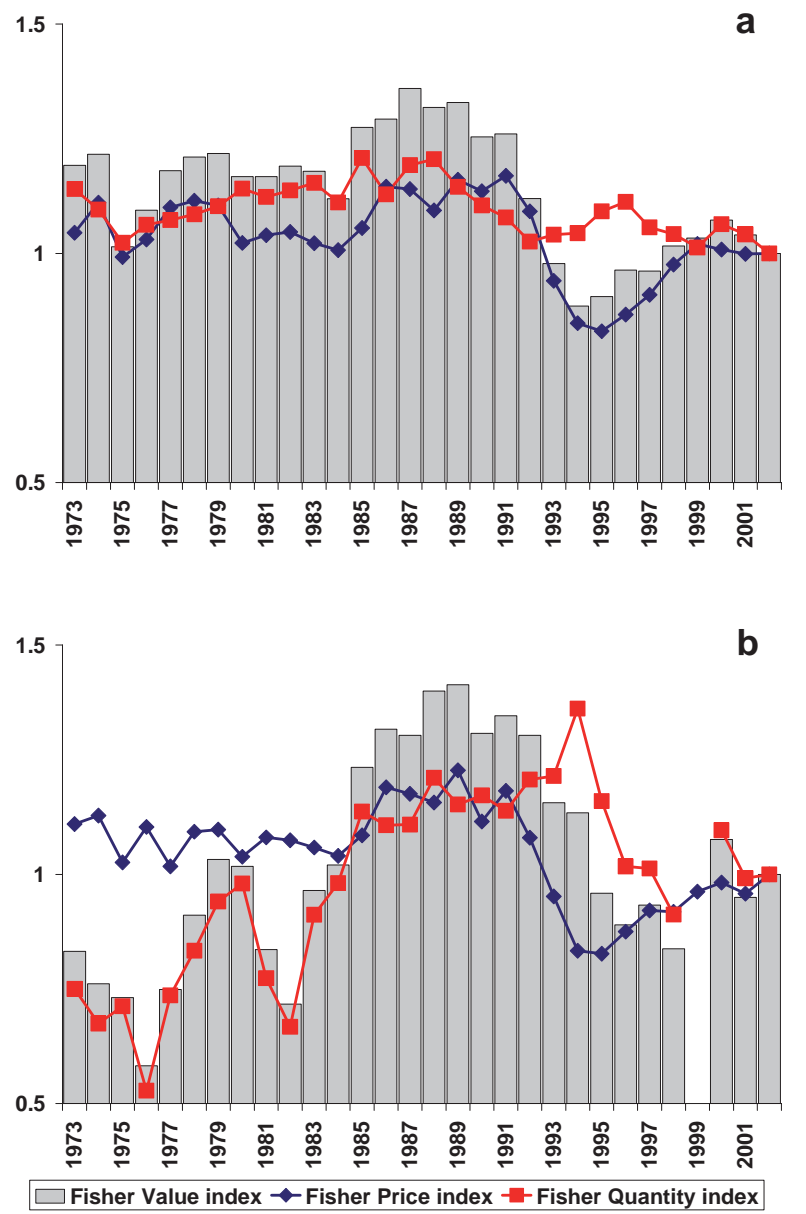

Fig. 2. Evolution of Fisher indices of the volume and value of total fish landings by French fleets fishing in (a) the NE Atlantic, 19732002 and (b) the Bay of Biscay, 1973-2005 (2002 fixed base and 2002 prices).

descriptors of the species; third, the results of the multivariate analysis of modifications in landing composition, and their relations with the economic characteristics of the fish species are presented and discussed.

\subsection{Volume and value trends in total landings of fish species}

\subsubsection{North-East Atlantic (Fig. 2a)}

The trends observed in the volume and value indices of landings of fish species originating from the NE Atlantic by French fleets are studied over the 1973-2002 period (Fig. 2a).

The total tonnage of fish landed reached a maximum in the mid-1980s and decreased from 1988, reaching lower levels in 2002 than in 1973. Following a period of relative stability, total value tended to increase in the late 1980s, reaching a maximum in 1987. This resulted in part from a steady increase in ex-vessel fish prices. The value of landings was then severely reduced, reaching a minimum in 1995 . While this was initially caused by a decrease in volumes landed, the collapse of the gross revenue of French fleets also resulted from a major drop 
in prices at first sale on the French market during the early 1990s (Steinmetz et al. 2006). This crisis was due to the liberalization of trade in fish products on the European markets on which fleets operate, leading to modifications in the conditions of competition between fish products on these markets and an increased sensitivity of trade to exchange rates between European currencies (Guillotreau and Péridy 2000). From 1996 onwards, the value of landings increased again, but not enough to fully compensate for the earlier drop.

\subsubsection{Bay of Biscay (Fig. 2b)}

The trends observed in the volume and value indices of landings of fish species originating from the Bay of Biscay by French fleets over the 1973 to 2002 period were also considered (Fig. 2b). Total tonnage of fish landed increased strongly until the mid-1990s, after which it started to decrease. Fluctuations in the landed value were greater at the scale of the Bay of Biscay than for the NE Atlantic as a whole, and tended to increase during the period 1983-1989, reaching a maximum in 1988-89. Landed value was then severely reduced during the years of market crisis, reaching a low point in 1998. While this collapse was initially due to the drop in prices already mentioned, it was further reinforced by a strong reduction in volumes of fish landed. At the end of the period, the total value of landings originating from the Bay of Biscay was however higher than in 1973.

Comparison of the two time series shows that a greater proportion of the total value of landings by French fleets originated from the Bay of Biscay during the first part of the period: (1973-1994). The ratio of the value of landings from the Bay of Biscay to the value of landings from the NE Atlantic moved from $23 \%$ to $45 \%$ in this time period. In the second part of the study period (1995-2002) this ratio fell, so that it was only $33 \%$ in 2002 . This is possibly because offshore fleets maintained and even increased their production while landings by inshore fleets, restricted to operating in the bay, declined severely. The reduction in inshore fleet size due to capacity reduction schemes (Thébaud et al. 2006) would have made a particular contribution to this effect.

\subsection{Species composition of landings}

Landing composition was first considered in terms of the contribution of different species groups to total production volume. The evolution of landings by French fleets are displayed at the two scales of analysis, considering three groups of species: benthic fishes (BEN), demersal fishes (DEM) and pelagic fishes (PEL). Estimated overall trends in landings for these three groups are presented (Table 3 ).

Overall, there was a marked decrease in the proportion of demersal fishes in landings by French fleets in the NE Atlantic over the study period, starting from the late 1980s. This was partly compensated by a slight, but temporary, increase in the proportion of benthic fishes, some of which fetch high prices. Composition of landings was mainly affected by a strong increase in the proportion of pelagic fishes, which approximately doubled over the study period.
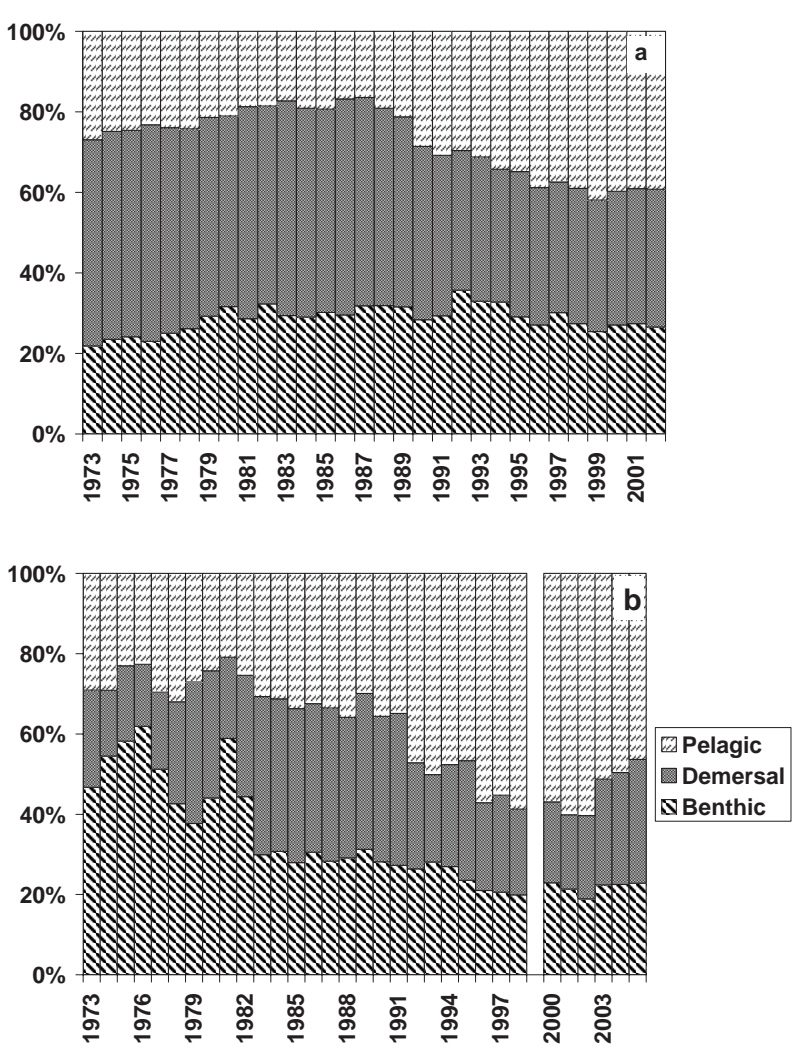

Fig. 3. Evolution of the composition of total fish landings by French fleets, originating from (a) the NE Atlantic, 1973-2002 and (b) the Bay of Biscay, 1973-2005 (the bathydemersal group, including only monkfish, has been added to the benthic group here).

A similar decline in the proportion of demersal fishes caught by French fleets in the Bay of Biscay was observed from the early 1990s (the group moved from $20 \%$ of landings in 1973 , to $40 \%$ in 1990 , then down to $20 \%$ in 2002). There was also a strong reduction in the proportion of benthic fishes, which moved from $45 \%$ of landings in 1973 to only $20 \%$ in 2002. There was a large increase in the proportion of pelagic fishes in the landings, starting in the 1980s: while the pelagic group represented $21 \%$ of landings in 1981, it accounted for $60 \%$ of production in 2002 .

\subsubsection{Bio-geographic descriptors}

The evolution of the mean trophic level of landings (Fig. 4), the mean maximum length of the landed species (Fig. 5), and the average of the median latitude of areas over which the landed species are known to be distributed (Fig. 6) are described below.

Following a period of high and relatively stable mean trophic level of the species landed until the late 1980s, a marked decrease in this index was observed for both time series. The early 1990s showed a particularly significant drop in the mean trophic level of species landed, indicating a change in the composition of landings, with an increase in the proportion of species from lower trophic levels. This is possibly due to changes in fishing strategy in response to the market crisis: an attempt was made to compensate for the sharp decreases 
Table 3. Trends in French landings (tons per year) of the three groups of species.

\begin{tabular}{|c|c|c|}
\hline & Bay of Biscay & NE-Atlantic \\
\hline Benthic fishes & ${ }^{* *}(-842$ tons per year) & $\rightarrow$ \\
\hline Demersal fishes & $\longrightarrow$ & ${ }^{* *}(-3363$ tons per year $)$ \\
\hline Pelagic fishes & * $(+982$ tons per year) & ${ }^{* *}(+2027$ tons per year $)$ \\
\hline
\end{tabular}

( *) Indicates the significance to $5 \%(* * 1 \%)$ of the Mann-Kendall trend test; the Sen's slope is indicated in the brackets.

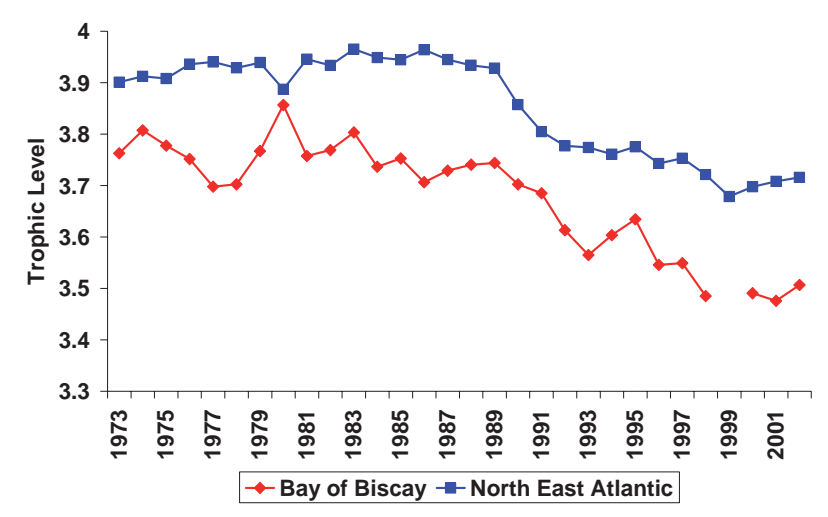

Fig. 4. Evolution of the mean trophic level of fish species landed by French fleets, originating from the Bay of Biscay and NE Atlantic areas, 1973-2002 (data for the year 1999 is missing from the ICES landings database).

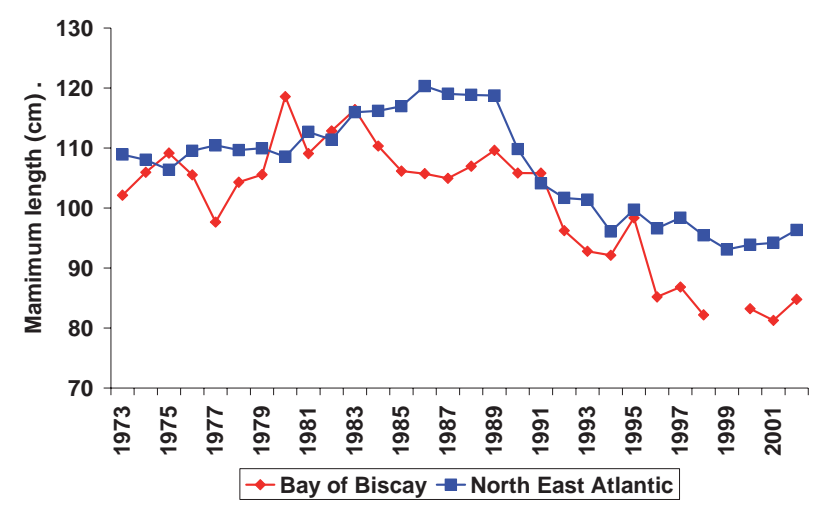

Fig. 5. Evolution of the mean maximal length of the fish species landed by French fleets, originating from the Bay of Biscay and NE Atlantic areas, 1973-2002.

in price imposed on French fleets, by an increase in volumes landed. The decline in this index continued in both areas until the end of the study period. Overall, the NE Atlantic index declined from 3.95 in the late 1980s to 3.7 in 2002. In the Bay of Biscay, there was a similar decline from 3.85 in 1980 to 3.5 in 2002.

The maximal length index (Fig. 5) also illustrates the modifications that have occurred in the composition of landings throughout the period. The evolution of this index shows a trend similar to that observed for the trophic level index: following a period of increase in the NE Atlantic and stagnation

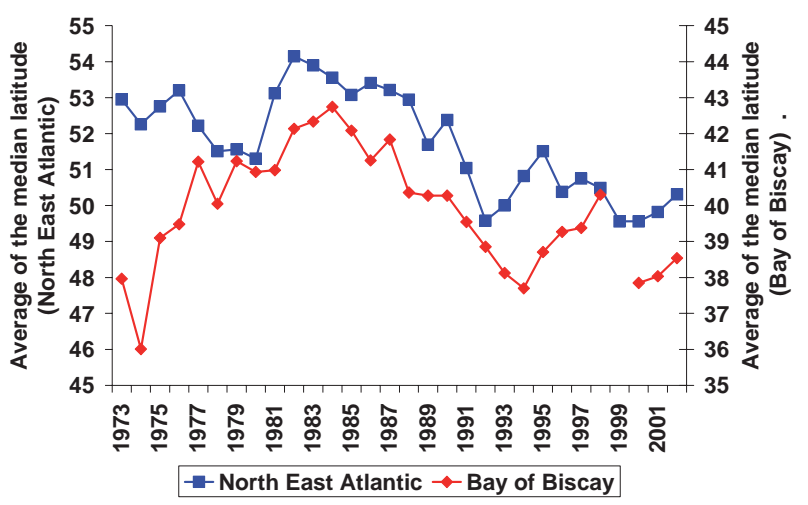

Fig. 6. Evolution of the mean latitude of distribution area of the fish species landed by French fleets, originating from (red diamonds, right axis) the Bay of Biscay and (blue squares, left axis) the NE Atlantic area, 1973-2002.

in the Bay of Biscay until the mid 1980ies, the index decreased steadily in the second half of the study period in the two areas.

The latitudinal index (Fig. 6) provides indications as to the potential influence of changes in climate and/or changes in the spatial distribution of fishing effort on modifications in the composition of landings. The index shows a declining trend starting in the mid 1980s for the two areas. In the NE Atlantic, the index reached its maximum in 1982 at $54^{\circ}$ and fell to $50^{\circ}$ in 2002. In the Bay of Biscay, the index reached a peak in 1984 with $42.5^{\circ}$ and lost four degrees at the end of the study period. We are not aware of any major redistribution of fishing effort towards the South by French fleets over the study period; hence these trends probably reflect the changing composition of fish communities due to changes in the relative abundance and/or accessibility of species in the areas considered, favouring the catch of sub-tropical species. This observation concurs with those derived from fishery-independent surveys on changes in the relative abundance of fish species in the fish community of the Bay of Biscay (Poulard and Blanchard 2005).

Overall, the three indices show that modifications in the composition of landings can be related both to changes in the strategies of fishing operators in response to changes in the economic conditions under which fleets operate, and to changes in the relative availability of fish species due to ecological factors. The following section presents an analysis of correlations between these modifications, the economic status of individual fish species, and total production by French fleets. 


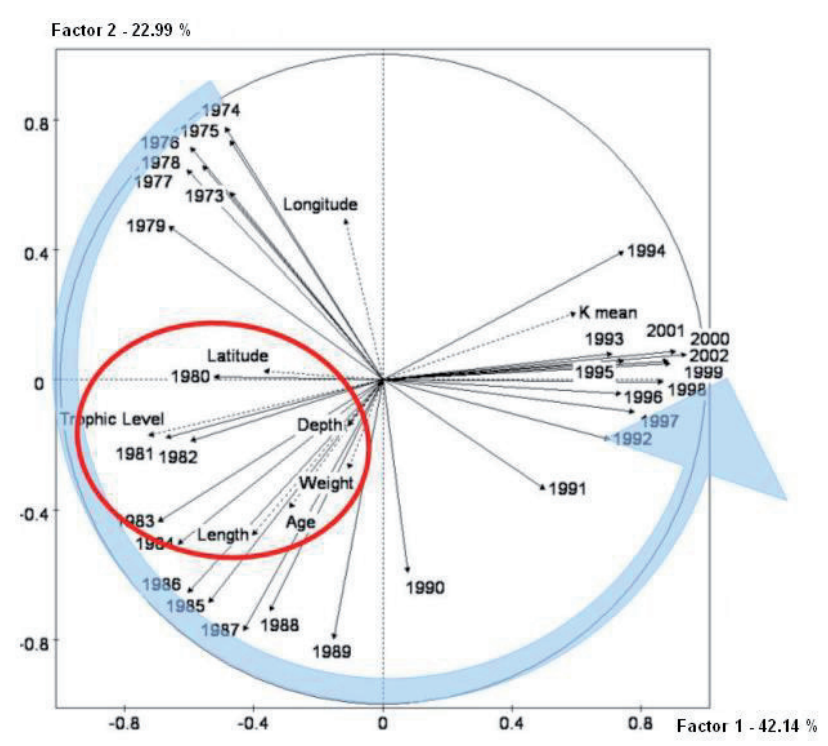

Fig. 7. Principal component analysis of the 30 active variables (years), 8 illustrative variables in the principal plane (first and second axes planes), for the NE Atlantic area.

\subsection{Multivariate analysis of changes in the structure of landings}

\subsubsection{NE Atlantic}

The correlogram of landings-years is presented using the first two principal components resulting from the analysis representing $65 \%$ of total variance in the data for the NE Atlantic (Fig. 7). The sequence of changes in landings per year can be followed along the arrow. The beginning of the period starts in the upper-left hand part of the graph. The mid-1980s are represented in the lower-left-hand part. Years 1990-1992 are in the bottom-right-hand part of the graph and the end of the period is represented in the right-hand part (Fig. 7).

Correlations between illustrative variables (bio-geographic descriptors) and the principal components are stressed by the inner circle. Latitude appears strongly correlated with the first axis of the principal component analysis: this corresponds to the fact that exploitation of high latitude species culminated in the early 1980s, while the contribution of low-latitude species progressively increased in the years that followed it. Other descriptors such as trophic level, maximum length and maximum age are positively correlated with landings in the early 1980s, while the growth rate $(\mathrm{K})$ of species is positively correlated with landings during the fisheries crisis years (1993-1994), and in the following years. The overall trends observed via descriptive analysis in the previous section are thus well summarized by the analysis presented here.

\subsubsection{Bay of Biscay}

The first three axes of the projection represent $34 \%, 18.8 \%$ and $15 \%$ of the variance in the Bay of Biscay data (Fig. 8). The sequence of changes in landings per year can be followed

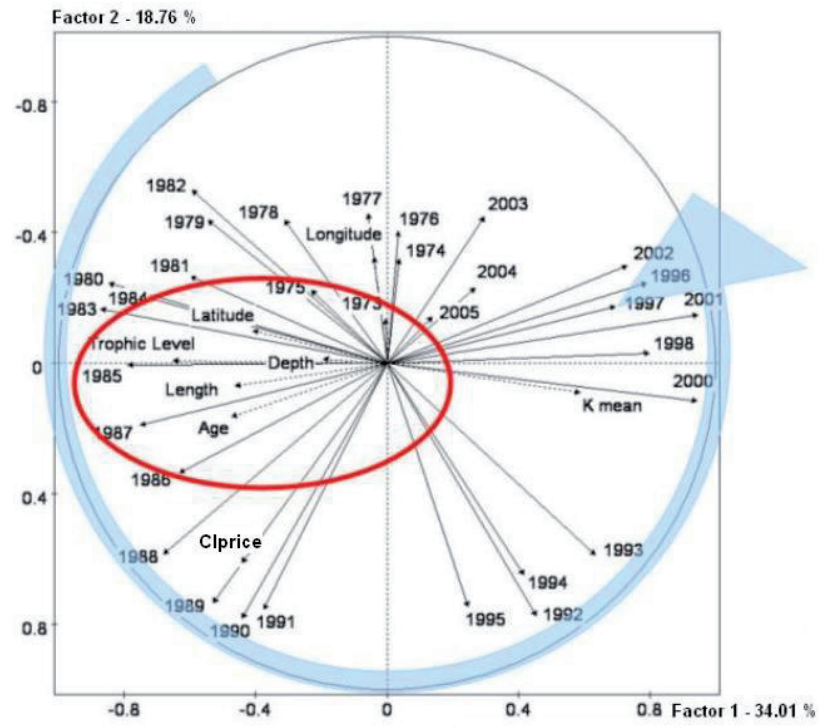

Fig. 8. Projection of the 33 active variables (years), 8 illustrative variables in the principal plane (first and second axes planes), for the Bay of Biscay area.

with the arrow. The first axis separates the mid-1980s from the 1998 to 2002 period, and the second axis isolates the 19881995 period.

The correlation of bio-geographic indices with the years of landings appears even stronger in this case than for the NE Atlantic. Mean latitude is positively correlated with landings at the beginning of the 1980s, and trophic level, maximum length and maximum age variables are strongly correlated with landings in the mid-1980ies. The growth coefficient variable was correlated with landings in the years around 2000. Again, changes observed in the composition of landings originating from the Bay of Biscay seem to be well synthesized by this analysis.

In this case, the price class of individual species (Fig. 1) was added as an illustrative variable (clprice) to the correlogram, in order to identify possible correlations between the years of landings and price categories of species. Highly priced species were mostly landed in the late 1980s whereas low priced species were exploited more recently (Fig. 8). Further analysis of this pattern is proposed below.

\subsubsection{Correlations with the economic status of individual species in the Bay of Biscay}

We examine the projection of the individuals in the first plane of the PCA for the Bay of Biscay case (Fig. 9, the size of the points is proportional to their contribution to the analysis).

This allows us to identify species such as sea bream or herring which have practically disappeared from landings over the period. The mid-1980s saw increases in the landings of pouting, followed by monkfish, a species of much higher price. The highest levels of landings of hake occurred towards the end of the 1980s. During the 1992-1995 crisis, landings of common sole reached their highest levels, and seem to have 


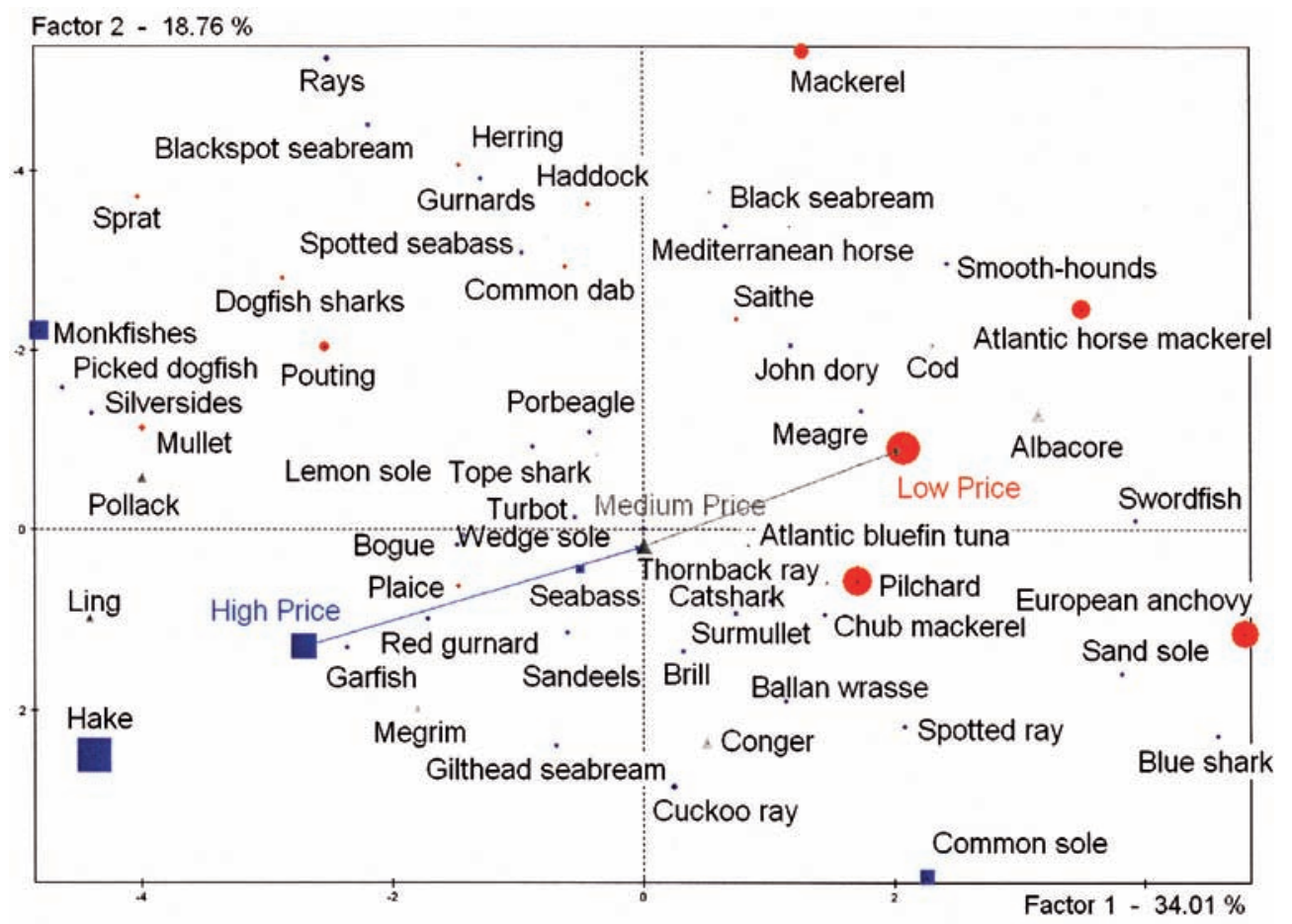

Fig. 9. Projection of the individuals (57 species) in the principal plane (first and second axes planes), for the Bay of Biscay area. Blue: high price calss, grey: medium price class; red: low price class.

played the role of a substitute species for fleets that were affected by the collapse of prices on the whitefish market. At the end of the study period, the highest exploitation levels for pelagic fish like anchovy, Atlantic horse mackerel, mackerel or albacore tuna are observed.

Using the price categories defined above, the projections of individual species in the first space of the PCA can be colourcoded, so as to assess whether correlations exist between the sequence of harvesting and the economic status of individual species. The projection including this price classification, and those from the centres of gravity of each of the three groups (low-, medium- and high-price species) are presented (Fig. 9).

While no conclusion can be derived concerning the medium-price group, the low-price group is clearly opposed to the high-price group in the projection. Largest landings of the low-price species were achieved during the later part of the time period, mainly from 1996 to 2002. On the other hand, the centre of gravity of the high-price group is located in the lower-left part of the space defined by the projection: largest landings for this group were achieved in the 1980s. In volume terms, the high-price group is mainly composed of species like hake, monkfish, sole or sea bass. John Dory (Zeus faber) is the main highly priced fish which appears in later years, but in small quantities.

The analysis thus lends support to the hypothesis that a correlation exists between the economic status of species caught in the Bay of Biscay and the sequence according to which they were harvested over the period 1973-2002. Overall, there appears to have been a transition during this period, from species fetching high prices on the market, to those fetching lower prices on the market.

\section{Discussion}

The results of this study can be used to further discuss the changes observed in the total value of production originating from the Bay of Biscay, as described by the index presented in Figure 2. Changes in the total value of landings can be explained as a consequence of three complementary factors: (i) changes in the total volumes landed; (ii) changes in the prices of the species landed; and (iii) changes in the relative weight of high/low price species in the total landings.

Total volumes landed have fluctuated significantly over the period considered. However, changes in the total value of landings have also resulted from modifications in the price index, due to changing conditions for the marketing of fish caught by French fleets rather than the fisheries themselves or their production. The relative influence of variations in price and volume of landings can be assessed using the ratio of logged Fisher indices over the logged value index. At the scale of the Bay of Biscay, the calculation for the year 2002 compared with 1989 , showed that $42 \%$ of total value changes were due to price variations, and $58 \%$ to changes in quantities landed.

Modifications in the composition of landings have also played a role in the changes in value landed. Indeed, when the total value index reached its maximum in the late 1980s, landings of high-priced species were also at their maximum. At the lower level of the value index in 1998, high exploitation rates for low-priced species such as anchovy or pilchard were observed, while low exploitation rates of high-priced species such as hake or monkfish prevailed. Hence, modifications in the composition of landings, as illustrated in the previous section, contribute to explaining the reduced value of fish production from the Bay of Biscay between the late 1980s and 2002. 
To quantify this structural effect, we can compare an index of the mean price of fish landed (defined as a simple average of individual species prices weighted by their annual contribution to total volumes landed), with a Laspeyres price index that weights individual species prices by their contribution to total volumes landed in 1989:

$$
F_{t / 0}^{p}=\frac{\sum\left(q_{i, 0} \cdot p_{i, t}\right)}{\sum_{i}\left(q_{i, 0} \cdot p_{i, 0}\right)} .
$$

Between 1989 and 2002, the index of mean price of fish landed by fleets operating in the Bay of Biscay moved from 1 to 0.56 , while the Laspeyres price index moved from 1 to 0.80 . The latter change provides an indication of what the drop in average price should have been, had the composition of landings remained the same between 1989 and 2002. From the mean price index, it is apparent that the drop in average price had indeed been much greater. This indicates that along with the overall reduction in prices across species, the growing proportion of low price species in total landings has exerted a downward pressure on the average price of fish production. The importance of this effect can be quantified by calculating the percentage of the drop in mean price, which can be explained by structural modifications in the composition of landings ${ }^{6}$ : the part of the decrease in prices explained when the structure is kept unchanged is calculated as the log of the Laspeyres price index, with 1989 as a base, divided by the log of the mean price index. This percentage equalled $62 \%$ of the total mean price change between the two years, which in this case was a drop of $44 \%$ : two thirds of the reduction in mean prices are thus due to the increased proportion of low-priced species in the landings.

\section{Conclusion}

The analyses presented in this paper allow us to identify important changes in the total value of landings by French fleets operating in the NE Atlantic and Bay of Biscay during the last three decades. Three complementary factors may contribute to explaining such changes: (i) modifications of the total volumes landed; (ii) modifications of the prices of each of the species landed; and (iii) changes in the composition of the landings. The analyses presented in this paper show that all three factors have contributed to the evolution of the value of fisheries production in the case studied. Total volumes landed have fluctuated significantly over the period considered. The price index of fish landed by French fleets has also varied to a significant extent, due to external factors relating to the marketing conditions for fish in France. While these two factors seem to explain a large proportion of the variations in the total value of production, modifications in the composition of landings, probably due in part to changes in fishing strategies that have developed to face the changes in biological communities, have also contributed to the evolution of fishery production value. High priced species were mostly exploited in the

\footnotetext{
${ }^{6}$ The share of structural effect can be calculated as the log of the
} Laspeyres price index divided by the log of the mean price index. early 1980s, with landings dominated by large boreal predator species such as monkfish or hake. In contrast, low-price species, such as anchovy or Atlantic horse mackerel, have dominated landings in more recent times (1996-2002). These species are characterized by lower trophic levels, smaller size and are more often sub-tropical. The lower value of landings in recent years as compared to the mid-1980s has partly resulted from this increase in the relative weight of lower valued species.

This case study of French fleets confirms that their production has been subject to species composition changes similar to those observed on wider scales. The inclusion of price data in the analysis allowed us to assess the implications of these changes in terms of the total gross value of production, and lends support to the hypothesis that the sequence of species harvesting is in part related to the relative economic attractiveness of fish species. Further work in this direction would involve quantification of the relative contributions of different factors to the overall evolution of gross fisheries production, and to the implications of these results for policy. Such work would particularly imply an analysis of the potential economic impacts of measures aiming to modify the composition of fishery landings.

Acknowledgements. This work was carried out as part of the "CHALOUPE" research project funded by the French National Research Agency, under its 2005 Biodiversity call for proposals (http://www.projet-chaloupe.fr).

\section{References}

Blanchard F., Vandermeirsch F., 2005, Warming and exponential abundance increase of the subtropical fish Capros aper in the Bay of Biscay (1973-2002). C.R. Acad. Sci. Biologies 328, 505-509.

Blanchard F., Thébaud O., Chevaillier P., Steinmetz F., Bonneaud S., Guyader O., Lorance P., Boucher J., 2006, Effets de la pêche et du réchauffement climatique sur le peuplement de poissons du golfe de Gascogne et conséquences pour les pêcheries. Programme IFB-GICC biodiversité et changement global, réponses adaptatives au changement global : résultats et prospective. Ifremer, colloque de restitution, Paris, 18-20 Sept. 2006, pp. 86-90.

Diewert W.E., 1996, Price and volume measures in the system of national accounts, in the new system of national accounts. In: Kendrick J.W. (Ed.), Dordrecht, Kluwer Academic Publishers, pp. 237-285.

Gilbert R.O., 1987, Statistical Methods for Environmental Pollution Monitoring. Van Nostrand Reinhold, New York.

Guillotreau P., Péridy N., 2000, Trade barriers and European imports of seafood products: a quantitative assessment. Mar. Policy 24, 431-437.

National Research Council, 2006, Dynamic changes in marine ecosystems: fishing, food webs, and future options. Washington DC, National Academy Press.

Pauly D., Christensen V., Dalsgaard J., Froese R., Torres Jr. F., 1998, Fishing down marine food webs. Science 279, 860-863.

Pauly D., Palomares M.L., Froese R., Sa P., Vakily M., Preikshot D., Wallace S., 2001, Fishing down Canadian aquatic food webs. Can. J. Fish. Aquat. Sci. 58, 51-62. 
Pinnegar J.K., Jennings S., O’Brien C.M., Polunin N.V.C., 2002, Long term changes in the trophic level of the Celtic sea fish community and fish market price distribution. J. Appl. Ecol. 39, 377390.

Poulard J.C., Blanchard F., 2005, The impact of climate change on the fish community structure of the eastern continental shelf of the Bay of Biscay. ICES J. Mar. Sci. 62, 1436-1443.

Quéro J.C., Vayne J.J., 1997, Les poissons de mer des pêches françaises. Paris, Delachaux et Niestlé.

Sen, P.K., 1968, Estimates of the regression coefficient based on Kendall's tau. J. Am. Stat. Assoc. 63, 1379-1389.

Steinmetz F. Thébaud O., Guyader O., Blanchard F., 2006, A preliminary analysis of long-term changes in the value of landings by French fishing fleets operating in the north-eastern Atlantic. Proc.13th Conference IIFET, Portsmouth 11-14 July 2006.

Sumaila U.R., 1998, Markets and the fishing down marine food webs phenomenon. Echo of Expo'98, Bull. 11, pp. 25-26.

Thébaud O., Daurès F., Guyader O., Travers M., Van Iseghem S., 2006, Modelling the adjustment of fishing fleets to regulatory controls: the case of South-Brittany trawlers (France), 1990-2003. AMURE working paper D13-2006 (http://www. gdr-amure.fr/).

Thébaud O., Soulié J.-C., 2008, Fishing through fish communities: a simple bio-economic model. Proc. International Congress on Modelling and Simulation, Christchurch, New Zealand, December 2007.

Appendix. List of species sorted by habitat and price class (average 1973-2002 ex-vessel price in constant 2002 euros). See Table 2 for the definition of price classes.

\begin{tabular}{|c|c|c|c|c|}
\hline \multirow[t]{2}{*}{ Common name } & \multirow[t]{2}{*}{ Scientific name } & \multicolumn{3}{|c|}{ Price of fish (2002 euros) } \\
\hline & & Class 1 & Class 2 & Class 3 \\
\hline \multicolumn{5}{|l|}{ Bathydemersal } \\
\hline Dogfish sharks & Squalidae & 1.265 & & \\
\hline Monkfishes & Lophius sp. & & & 4.315 \\
\hline \multicolumn{5}{|l|}{ Benthic } \\
\hline Black seabream & Spondyliosoma cantharus & & 3.198 & \\
\hline Blackspot seabream & Pagellus bogaraveo & & & 7.218 \\
\hline Cod & Gadus morhua & & 2.353 & \\
\hline Herring & Clupea harengus & 0.599 & & \\
\hline John dory & Zeus faber & & & 7.805 \\
\hline Meagre & Argyrosomus regius & & & \\
\hline Picked dogfish & Squalus acanthias & & & \\
\hline Pollack & Pollachius pollachius & & 2.913 & \\
\hline Pouting & Trisopterus luscus & 0.725 & & \\
\hline Tope shark & Galeorhinus galeus & & & \\
\hline Whiting & Merlangius merlangus & 1.400 & & \\
\hline \multicolumn{5}{|l|}{ Demersal } \\
\hline Bogue & Boops boops & & & \\
\hline Brill & Scophthalmus rhombus & & & 8.041 \\
\hline Common dab & Limanda limanda & 1.593 & & \\
\hline Common sole & Solea solea & & & 9.601 \\
\hline Conger & Conger conger & & 1.822 & \\
\hline Cuckoo ray & Leucoraja naevus & & & \\
\hline Gilthead seabream & Sparus aurata & & & 9.322 \\
\hline Gurnards & Trigla spp. & & & \\
\hline Haddock & Melanogrammus aeglefinus & 1.372 & & \\
\hline Hake & Merluccius merluccius & & & 4.618 \\
\hline Lemon sole & Microstomus kitt & & 3.494 & \\
\hline Ling & Molva molva & & 1.770 & \\
\hline Megrim & Lepidorhombus whiffiagonis & & 3.322 & \\
\hline Plaice & Pleuronectes platessa & 1.421 & & \\
\hline Rays & Rajidae & & & \\
\hline Red gurnard & Aspitrigla cuculus & & & \\
\hline Saithe & Pollachius virens & 1.124 & & \\
\hline
\end{tabular}


Appendix. Continued.

\begin{tabular}{|c|c|c|c|c|}
\hline \multirow{2}{*}{ Common name } & \multirow[t]{2}{*}{ Scientific name } & \multicolumn{3}{|c|}{ Price of fish (2002 euros) } \\
\hline & & Class 1 & Class 2 & Class 3 \\
\hline Sand sole & Pegusa lascaris & & & \\
\hline Sandeels & Ammoditidae & & & \\
\hline Seabass & Dicentrarchus labrax & & & 11.628 \\
\hline Smooth-hounds & Mustelus sp. & & & \\
\hline Spotted ray & Raja montagui & & & \\
\hline Surmullet & Mullus surmuletus & & & 8.892 \\
\hline Thornback ray & Raja clavata & & 2.159 & \\
\hline Turbot & Scophthalmus maximus & & & 10.983 \\
\hline Wedge sole & Dicologoglossa cuneata & & 3.662 & \\
\hline \multicolumn{5}{|l|}{ Pelagic } \\
\hline Albacore & Thunnus alalunga & & 3.668 & \\
\hline Atlantic bluefin tuna & Thunnus thynnus & & 3.941 & \\
\hline Atlantic horse mackerel & Trachurus trachurus & 0.595 & & \\
\hline Blue shark & Prionace glauca & & & \\
\hline Chub mackerel & Scomber japonicus & & & \\
\hline European anchovy & Engraulis encrasicolus & 1.372 & & \\
\hline Garfish & Belone belone & & & \\
\hline Mackerel & Scomber scombrus & 0.707 & & \\
\hline Mediterranean horse mackerel & Trachurus mediterraneus & & & \\
\hline Mullet & Mugilidae & 1.634 & & \\
\hline Pilchard & Sardina pilchardus & 0.795 & & \\
\hline Porbeagle & Lamna nasus & & & \\
\hline Silversides & Atherina sp. & & & \\
\hline Small-spotted catshark & Scyliorhinus canicula & & & \\
\hline Spotted seabass & Dicentrarchus punctatus & & & \\
\hline Sprat & Sprattus sprattus & 0.448 & & \\
\hline Swordfish & Xiphias gladius & & & \\
\hline \multicolumn{5}{|l|}{ Recifal } \\
\hline Ballan wrasse & Labrus bergylta & & & \\
\hline
\end{tabular}

